\title{
Microbial processes in a high-latitude fjord (Kongsfjorden, Svalbard): II. Ciliates and dinoflagellates
}

\author{
Lena Seuthe • Kriss Rokkan Iversen • \\ Fanny Narcy
}

Received: 23 November 2009/Revised: 4 November 2010/Accepted: 8 November 2010/Published online: 2 December 2010

(C) The Author(s) 2010. This article is published with open access at Springerlink.com

\begin{abstract}
The composition and ecological role of ciliates and dinoflagellates were investigated at one station in Kongsfjorden, Svalbard, during six consecutive field campaigns between March and December 2006. Total ciliate and dinoflagellate abundance mirrored the seasonal progression of phytoplankton, peaking with $5.8 \times 10^{4}$ cells $1^{-1}$ in April at an average chlorophyll $a$ concentration of $10 \mu \mathrm{g} \mathrm{l^{-1 }}$. Dinoflagellates were more abundant than ciliates, dominated by small athecates. Among ciliates, aloricate oligotrichs dominated the assemblage. A large fraction $(>60 \%)$ of ciliates and dinoflagellates contained chloroplasts in spring and summer. The biomass of the purely heterotrophic fraction of the ciliate and dinoflagellate community (protozooplankton) was with $14 \mu \mathrm{g} \mathrm{C}^{-1}$ highest in conjunction with the phytoplankton spring bloom in April. Growth experiments revealed similar specific growth rates for heterotrophic ciliates and dinoflagellates $\left(<0-0.8 \mathrm{~d}^{-1}\right)$. Food availability may have controlled the protozooplankton assemblage in winter, while copepods may have exerted a strong control during the post-bloom period. Calculations of the potential
\end{abstract}

L. Seuthe $(\bowtie) \cdot$ K. Rokkan Iversen

Department of Arctic and Marine Biology,

Faculty of Biosciences, Fisheries and Economics,

University of Troms $\varnothing, 9037$ Troms $\varnothing$, Norway

e-mail: lena.seuthe@uit.no

F. Narcy

Norwegian Polar Institute, 9296 Troms $\varnothing$, Norway

F. Narcy

Laboratoire d'Océanographie de Villefranche, UPMC,

Univ Paris 06, UMR 7093, 06234 Villefranche-sur-mer, France

F. Narcy

Laboratoire d'Océanographie de Villefranche, CNRS,

UMR 7093, 06234 Villefranche-sur-mer, France grazing rates of the protozooplankton indicated its ability to control or heavily impact the phytoplankton stocks at most times. The results show that ciliates and dinoflagellates were an important component of the pelagic food web in Kongsfjorden and need to be taken into account when discussing the fate of phytoplankton and biogeochemical cycling in Arctic marine ecosystems.

Keywords Microzooplankton - Mesozooplankton · Phytoplankton · Food web - Carbon cycling · Arctic

\section{Introduction}

Protozoans, such as heterotrophic ciliates and dinoflagellates, are major grazers on bacteria, flagellates, and diatoms in temperate marine environments (Sherr et al. 1989; Johansson et al. 2004; Aberle et al. 2007; Sherr and Sherr 2007). In cold waters, where large copepods were considered the principal grazers, the role of protozoans was traditionally thought to be of minor importance. A global comparison of the impact of protozoan grazers on phytoplankton did, however, not support such a dissimilarity between different geographic regions, but showed protozoan grazing to be the major source of phytoplankton consumption worldwide (Calbet and Landry 2004). In a cross-latitude comparison between the subpolar Disko Bay (Greenland) and temperate Kattegat (Denmark), Levinsen and Nielsen (2002) demonstrated that heterotrophic ciliates and dinoflagellates were important components of plankton in both systems, with similar seasonal patterns in abundance, taxonomic composition, and grazing impact. Yet the few studies on protozoan grazing in Arctic marine systems do indicate strong seasonal and spatial variability (Hansen et al. 1996; Sherr et al. 2009). Thus, the general role of 
protozooplankton for carbon cycling throughout the panArctic region is complex and not easily summarized.

The reported variability certainly reflects the extreme heterogeneity of Arctic marine systems, which are subjected to strong seasonality in light, temperature, and ice cover. At the same time, these studies also suggest strong biotic factors controlling the protozoan abundance. In the central Arctic, for example, Sherr et al. (2003) found the protozoan biomass to increase along with phytoplankton during spring and summer, indicating strong bottom-up control, while Rysgaard et al. (1999) reported strong topdown control by copepods in an ice-covered northeast Greenlandic fjord. In Disko Bay, West Greenland, the protozoan community was primarily controlled by the availability of food, but temporally also by copepod predation (Levinsen and Nielsen 2002). Ciliates and dinoflagellates build up a high biomass only when the dominating large copepods were absent from the euphotic zone in early spring and late summer (Levinsen and Nielsen 2002). Understanding the role and impact of protozoans in the food web thus demands particular consideration of key biotic factors, such as food availability and concentration of predators.

The Svalbard archipelago $\left(74-81^{\circ} \mathrm{N}\right)$ is situated at the boundary of the European Arctic. Warm Atlantic water is carried along the west coast of Spitsbergen by the West Spitsbergen Current, the northernmost extension of the North Atlantic Current (Loeng 1991). The west coast harbours large glacial fjord systems, one of which is Kongsfjorden $\left(79^{\circ} \mathrm{N} 12^{\circ} \mathrm{E}\right)$. The fjord has a wide opening and lacks a sill, which allows warm Atlantic water to advect into the fjord (Svendsen et al. 2002; Cottier et al. 2005). The copepod community of Kongsfjorden is known to heavily depend on these advective processes (Kwasniewski et al. 2003; Basedow et al. 2004; Willis et al. 2006; Walkusz et al. 2009). It is not clear to which extent the biomass-dominating large copepods, Calanus finmarchicus and $C$. glacialis, maintain local populations in the fjord (Walkusz et al. 2009). Their abundance, however, depends noticeably on the timing and magnitude of the shelf-fjord water mass exchanges (Kwasniewski et al. 2003; Walkusz et al. 2009), and the phytoplankton bloom in spring may often develop in the absence of significant stocks of copepods (Willis et al. 2006).

Despite extensive interest in the mesozooplankton fauna of Kongsfjorden (Hop et al. 2002, 2006 and references therein), no study has so far focused on the protozoan part (heterotrophic ciliates and dinoflagellates) of the zooplankton. Sparse accounts of dinoflagellates have been provided in the phytoplankton literature of the fjord (Hasle and Heimdal 1998; Keck et al. 1999; Wiktor 1999; Okolodkov et al. 2000; Wiktor and Wojciechowska 2005), while no reports exist on the ciliate assemblage in
Kongsfjorden, to the best of our knowledge. Consequently, the description of the zooplankton community in Kongsfjorden lacks a key component. Further, seasonal cycles from Arctic marine ecosystems are rare and missing from Kongsfjorden.

The present work is first of all an attempt to fill some of these knowledge gaps by providing seasonal ciliate and dinoflagellate abundance and biomass data from Kongsfjorden. It also tries to investigate some of the regulatory mechanisms that control protozoan biomass. Finally, it attempts to estimate the potential grazing impact of heterotrophic ciliates and dinoflagellates.

Concomitantly with the present study, biomass measurements of bacteria, picoplankton, and nanoflagellates, as well as primary production, were conducted in Kongsfjorden (Rokkan Iversen and Seuthe accepted). These data show that the microbial food web in Kongsfjorden was seasonally pulsed, with a peak in biomass in spring and relatively low biomass thereafter. The vernal phytoplankton bloom advanced in April, dominated by the prymnesiophyte Phaeocystis pouchetii and diatoms. Apart from the vernal bloom, phytoplankton was dominated by cells $<10 \mu \mathrm{m}$. Bacterial biomass peaked after the senescence of the phytoplankton bloom in May and remained high throughout the summer, sustaining a microbial food web of pico- and nano-sized heterotrophs.

\section{Material and methods}

\section{Locality and sampling}

The study was conducted at a station located in Kongsfjorden on the west coast of Spitsbergen $\left(78^{\circ} 57^{\prime} \mathrm{N}\right.$, $11^{\circ} 56^{\prime} \mathrm{E}$, approx. depth $300 \mathrm{~m}$, Fig. 1). The station was sampled in 2006 on March 18, April 25, May 30, July 4, September 16, and December 2. Vertical profiles of temperature and salinity were recorded on each occasion (Seabird SBE19+). Water was sampled with Niskin bottles from six discrete depths $(1,5,10,15,25$, and $50 \mathrm{~m})$ for the analyses of chlorophyll $a(\mathrm{Chl} a)$, protozooplankton, and phytoplankton. For analyses of $\mathrm{Chl} a$, triplicate subsamples (25-1,000 ml) were filtered onto Whatman GF/F glass fibre filters. The filters were frozen $\left(-20^{\circ} \mathrm{C}\right)$ immediately for 5-7 days, before being analysed fluorometrically (10-AU, Turner Designs) after extraction in $5 \mathrm{ml}$ of methanol at room temperature in the dark for $12 \mathrm{~h}$. All biological data processed from discrete water samples were integrated for the upper $50 \mathrm{~m}$ of the water column, using trapezoidal integration. Metazooplankton was sampled with WP2 net (mesh size of $63 \mu \mathrm{m}$, except for September and December when a mesh size of $90 \mu \mathrm{m}$ was used), hauled vertically from $200 \mathrm{~m}$ to the surface. 
Protist biomass and taxonomic composition

Samples for diatom, ciliate, and dinoflagellate identification and enumeration (500-1,000 ml) were fixed with acid Lugol ( $2 \%$ vol. final concentration). The samples were stored dark and cool, before being gently concentrated down to $50 \mathrm{ml}$ by inverse gravitational filtration $(10-\mu \mathrm{m}$ mesh size) after settling in a glass cylinder for $48 \mathrm{~h}$. From the concentrate, a subsample $(10 \mathrm{ml})$ was settled in an Utermöhl sedimentation chamber. The whole chamber was examined under an inverted microscope (Nikon TE200) at a magnification of $\times 200$ and $\times 400$. Cell sizes were measured on 30 specimens of each species using a camera (5 Mega pixel) attached to the microscope. Standard geometric forms were used to determine the cellular volume from length and width measurements. The biovolume was converted to biomass using a volume to carbon conversion

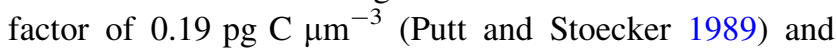
$0.053 \mathrm{pg} \mathrm{C} \mathrm{m}^{-3}$ (Verity and Langdon 1984) for aloricate and loricate ciliates, respectively. For dinoflagellates, a carbon conversion factor of pg $\mathrm{C}$ cell $^{-1}=0.760 \times$ volume $^{0.819}$ (Menden-Deuer and Lessard 2000) was used.

For ciliates, loricate (tintinnids) and aloricate forms were distinguished, with aloricates being divided into oligotrichs (Laboea strobila, Strombidium conicum, and Strombidium spp.), aloricate choreotrichs (Leegaardiella

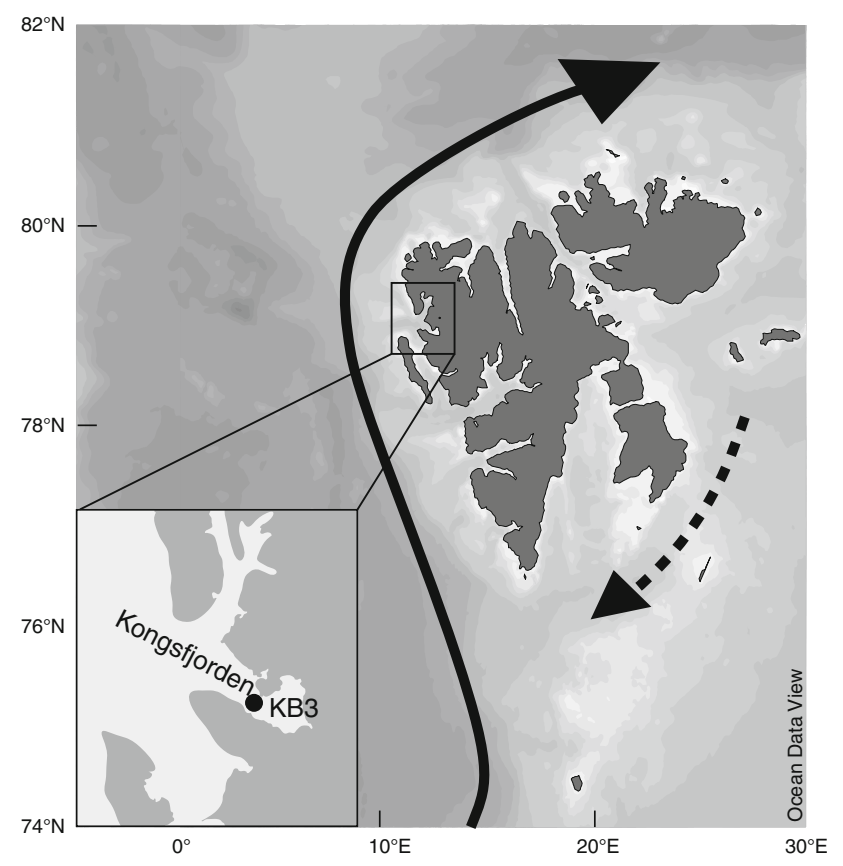

Fig. 1 Schematic overview over the main current system around the Svalbard Archipelago, with the West Spitsbergen Current (black arrow) transporting warm Atlantic water along the west coast of Spitsbergen. The present study was conducted in Kongsfjorden (station $\mathrm{KB} 3,78^{\circ} 57^{\prime} \mathrm{N}, 11^{\circ} 56^{\prime} \mathrm{E}$, ca. $300 \mathrm{~m}$ ) at the west coast of Spitsbergen sp., Lohmanniella sp., and Strobilidium sp.), Myrionecta rubra, and holotrichs (here used for all ciliates with even cilia coverage of the cell). Dinoflagellates were identified to the lowest taxonomic level possible and divided into thecates and athecates. Athecate dinoflagellates were divided into two size groups of equivalent spherical diameter (ESD) of smaller and larger than $20 \mu \mathrm{m}$.

Protozooplankton was divided into two groups depending on the presence or absence of chloroplasts, respectively, called phototrophs and heterotrophs hereafter. Since fixation with acid Lugol largely prohibits the visual examination of the presence of chloroplast, the division was undertaken according to literature. In ciliates, chloroplast-bearing species were Myrionecta rubra (Hansen and Fenchel 2006), Laboea strobila (Stoecker et al. 1988; Stoecker and Michaels 1991), Tontonia sp. (Laval-Peuto and Rassoulzadegan 1988), and Strombidium conicum (Stoecker and Michaels 1991), with the three latter ones being mixotrophs. In dinoflagellates, chloroplast-bearing species were identified according to Thomas (1997). All species classified as plastidic are indicated in Table 1.

\section{Protozoan growth experiments}

Protozooplankton growth rates were calculated from changes in cell abundance in the natural plankton community over the course of 2 days. Incubation water was sampled from the respective depths $(1,5,10,15,25,50 \mathrm{~m})$ at the same station and time as the profile using an acid-washed Go Flo bottle. The water from the different depths was pooled in equal parts in a 20-1 acid-washed Nalgene polycarbonate bottle. The pooled incubation water was gently pre-screened on $63 \mu \mathrm{m}$ by reverse filtration to exclude larger predators, which might have led to the loss of larger protozoans (e.g., tintinnids). In March, incubation water was taken from the surface by a 20 -1 acid-washed Nalgene polycarbonate bottle only, because very low air temperatures and strong wind made it impossible to handle the Go Flo bottle without freezing. On all occasions, the pre-screened incubation water was carefully siphoned over into three acid-washed polycarbonate bottles (Nalgene, 2.51 ), which were incubated in the dark at $2 \pm 1^{\circ} \mathrm{C}$ (March, April, May) and $4 \pm 1{ }^{\circ} \mathrm{C}$ (July, September). The incubation temperatures did not mirror in situ temperatures precisely, due to technical restrictions. The change in incubation temperature between spring and summer attempted to mirror the increase in in situ temperatures. The incubation bottles were gently rotated each day before sampling to homogenize the sample. Aliquots of $500 \mathrm{ml}$ were taken in the beginning $\left(t_{1}\right)$ and in the end $\left(t_{2}\right)$ of the experiment and fixed with acid Lugol ( $2 \%$ vol. final concentration) for later quantification.

Growth rates $(\mu)$ were calculated for different protozooplankton morphotypes (athecate dinoflagellates ESD 
Table 1 Species-specific integrated $(0-50 \mathrm{~m})$ abundance $\left(\right.$ cells $\times 10^{6}$ cells $\left.\mathrm{m}^{-2}\right)$ and biomass $\left(\mathrm{mg} \mathrm{C}^{-2}\right.$; in brackets) of dinoflagellates and ciliates

\begin{tabular}{|c|c|c|c|c|c|c|}
\hline & Mar & Apr & May & Jul & Sep & Dec \\
\hline \multicolumn{7}{|l|}{ Thecate dinoflagellates } \\
\hline Alexandrium minutum* & & $20(5)$ & & $14(4)$ & $13(3)$ & \\
\hline Alexandrium sp.* & & $46(12)$ & $12(3)$ & $36(10)$ & $0.8(0.2)$ & $0.2(0.04)$ \\
\hline Ceratium arcticum* & & & & $0.1(1)$ & & \\
\hline C. macroceros* & & & & & $0.4(3)$ & \\
\hline Dinophysis acuminata* & & & $1(2)$ & & & $0.1(0.2)$ \\
\hline Dinophysis sp. & & & & $0.3(0.7)$ & $0.3(0.7)$ & \\
\hline Diplopelta parva & $4(3)$ & & & & & \\
\hline Gonyaulax grindleyi* & $0.6(4)$ & & & & & \\
\hline G. scrippsiella* & $0.03(0.03)$ & & & & & \\
\hline Heterocapsa rotundata* & $3(0.1)$ & & & & & \\
\hline H. triquetra* & & $266(231)$ & & & & \\
\hline Lessardia elongata & $16(1)$ & & & & & \\
\hline Scrippsiella trochoidea* & & $8(3)$ & & & $0.3(0.1)$ & \\
\hline Oxytoxum criophilum* & $3(0.5)$ & & & & & \\
\hline Peridinium subinerme & $0.03(0.1)$ & & & & & \\
\hline Protoperidinium bipes & & $45(14)$ & & $19(6)$ & $31(10)$ & \\
\hline P. brevipes & & & & & $26(27)$ & \\
\hline$P$. divergens & & & & $0.3(1)$ & & \\
\hline P. granii & & $0.6(2)$ & & $0.1(0.4)$ & & \\
\hline P. pallidum* & & $0.2(2)$ & & & $0.05(0.2)$ & \\
\hline P. pellucidum & & $11(36)$ & $0.2(0.7)$ & $1(5)$ & $0.7(2)$ & \\
\hline P. steinii & & & & & & $0.4(1)$ \\
\hline Protoperidinium sp. 1 & & & & $0.2(3)$ & & \\
\hline Protoperidinium sp. 2 & & $54(174)$ & $1(4)$ & $1(4)$ & $1(4)$ & \\
\hline Total thecates & $27(9)$ & $451(480)$ & $15(11)$ & $73(33)$ & $74(51)$ & $0.7(2)$ \\
\hline \multicolumn{7}{|l|}{ Athecate dinoflagellates } \\
\hline Amphidinium crassum & $5(1)$ & & & & & \\
\hline A. fusiforme* & $8(1)$ & & & & & \\
\hline A. larvale* & $2(0.1)$ & & & & & \\
\hline A. longum & $4(0.7)$ & & & & & \\
\hline A. sphaenoides & $1(0.1)$ & $0.1(0.01)$ & & & & \\
\hline Gymnodinium albulum & $7(0.2)$ & & & & & \\
\hline G. arcticum $^{*}$ & $0.1(0.03)$ & $1902(991)$ & $197(103)$ & $29(15)$ & $76(39)$ & $42(22)$ \\
\hline G. japonicum* & $4(0.2)$ & & & & & \\
\hline G. pulchellum* & & $13(0.5)$ & & & $501(18)$ & $199(7)$ \\
\hline G. simplex* & & & & & $15(0.5)$ & \\
\hline G. wulfii & $2(0.2)$ & $266(28)$ & $57(6)$ & & & \\
\hline Gymnodinium sp. 1 & $7(11)$ & $11(17)$ & & $0.4(0.5)$ & & $19(28)$ \\
\hline Gymnodinium sp. 2 & $0.03(0.1)$ & & $5(8)$ & & & \\
\hline Gymnodinium sp. 3 & & & & & $4(6)$ & \\
\hline Gymnodinium sp. 4 & & $6(9)$ & $0.3(0.4)$ & & $1(2)$ & \\
\hline Gyrodinium aureolum & $0.3(0.7)$ & & & & & \\
\hline G. calyptroglyphe & $9(2)$ & & & & & \\
\hline G. fusiforme & & $21(24)$ & $7(8)$ & $1(1)$ & $9(10)$ & $0.1(0.1)$ \\
\hline G. lachryma & & $8(55)$ & $2(11)$ & $0.1(0.8)$ & $1(9)$ & \\
\hline G. pingue & $3(4)$ & & & & & \\
\hline Gyrodinium sp. 1 & & $4(0.9)$ & & & $25(5)$ & $50(10)$ \\
\hline
\end{tabular}


Table 1 continued

\begin{tabular}{|c|c|c|c|c|c|c|}
\hline & Mar & Apr & May & Jul & Sep & Dec \\
\hline Gyrodinium sp. 2 & & & $32(7)$ & & $191(39)$ & \\
\hline Gyrodinium sp. 3 & & $10(87)$ & & $0.2(2)$ & $0.3(2)$ & \\
\hline Karlodinium veneficum* & $6(0.7)$ & & & & & \\
\hline Katodinium glaucum & $4(0.6)$ & $21(3)$ & $0.5(0.1)$ & & $9(1)$ & $30(4)$ \\
\hline Nematodinium sp. & & & & & $0.3(2)$ & $0.1(0.4)$ \\
\hline Pronoctiluca pelagica & & & & & $4(2)$ & $0.2(0.1)$ \\
\hline Torodinium robustum* & $4(3)$ & & & & & \\
\hline T. teredo* & & & & & $0.5(0.4)$ & $1(0.4)$ \\
\hline Total athecates & $67(26)$ & $2,263(1214)$ & $301(143)$ & $31(20)$ & $835(135)$ & $342(73)$ \\
\hline \multicolumn{7}{|l|}{ Loricate ciliates } \\
\hline Acanthostomella cf. norvegica & & & & $0.3(0.2)$ & & \\
\hline Parafavella sp. & & & & $0.1(0.2)$ & $2(3)$ & \\
\hline Ptychocylis sp. & & & & & $0.5(20)$ & $0.1(3)$ \\
\hline Salpingella sp. & & & & & $0.4(0.9)$ & $0.2(0.5)$ \\
\hline Tintinnida indet. & & $6(168)$ & $2(63)$ & $1(47)$ & $2(101)$ & $1(40)$ \\
\hline Total loricates & & $6(168)$ & $2(63)$ & $2(47)$ & $5(125)$ & $1(43)$ \\
\hline \multicolumn{7}{|l|}{ Aloricate ciliates } \\
\hline Didinium cf. gargantua & & & & & & $0.03(0.1)$ \\
\hline Laboea strobila* & & $16(291)$ & $0.5(9)$ & $7(130)$ & $0.5(10)$ & \\
\hline Leegaardiella cf. ovalis & & $0.1(2)$ & & $0.2(5)$ & $0.4(8)$ & $2(37)$ \\
\hline Lohmanniella cf. oviformis & & $3(3)$ & $2(2)$ & & $1(1)$ & \\
\hline Myrionecta rubra* & $8(48)$ & $6(39)$ & $0.7(4)$ & & $0.1(0.6)$ & $0.3(2)$ \\
\hline Strombidium cf. acuminata & & $0.2(0.5)$ & & & & \\
\hline S. conicum $*$ & $2(6)$ & $34(91)$ & $8(21)$ & $2(5)$ & $0.5(1)$ & $0.5(1)$ \\
\hline S. wulffi & & $87(59)$ & $10(7)$ & $1(0.7)$ & $2(1)$ & $2(1)$ \\
\hline Strombidium sp. 1 & & $7(1)$ & $8(1)$ & & & $0.2(0.03)$ \\
\hline Strombidium sp. 2 & & $2(5)$ & & & & \\
\hline Strombidium sp. 3 & & $9(6)$ & $3(2)$ & $0.4(0.3)$ & $0.4(0.3)$ & $0.3(0.2)$ \\
\hline Strombidium sp. 4 & & $0.2(0.4)$ & & & $0.4(0.8)$ & \\
\hline Strobilidium $\mathrm{cf}$ spiralis & & & & & & $0.3(7)$ \\
\hline Tontonia sp.* & & $0.1(0.1)$ & & & & $0.1(0.05)$ \\
\hline Holotrich ciliates & $8(56)$ & $3(24)$ & & & $0.05(0.3)$ & $0.4(3)$ \\
\hline Total aloricates & 18 (110) & $168(522)$ & $32(46)$ & $11(142)$ & $5(24)$ & $6(51)$ \\
\hline
\end{tabular}

Species reported to contain chloroplasts or cleptochloroplasts are marked (*)

10-20, 20-30 $\mu \mathrm{m}$, Protoperidinium sp., aloricate ciliates ESD 10-20, 20-30, >40 $\mu \mathrm{m}$, and holotrich ciliates) assuming exponential growth: $\mu=\left(\ln N_{t 2}-\ln N_{t 1}\right) t^{-1}$, where $N_{t 2}$ and $N_{t 1}$ are the number of protozooplankton at time $t_{2}$ and $t_{1}$, respectively, given in days. Growth rates were calculated only for morphotypes of which $>20$ specimens were counted. Unfortunately, no growth was measured for tintinnids, which contributed significantly to the biomass of heterotrophic ciliates. Therefore, the growth rate of tintinnids was assumed to have been $0.38 \mathrm{~d}^{-1}$ at $5^{\circ} \mathrm{C}$ (Hansen and Jensen 2000) and corrected to in situ temperatures with a $Q_{10}$ of 2.8 (Hansen et al. 1997), for further calculations of the production and grazing rate of heterotrophic ciliates.

Protozoan production and grazing calculations

Daily production and grazing rates were calculated for heterotrophic ciliates and dinoflagellates only, excluding mixotrophic species. Protozoan production was calculated from the experimentally determined growth rates multiplied by the respective heterotrophic ciliate and dinoflagellate biomass. Protozoan growth rates were corrected to in situ temperature using a $Q_{10}$ of 2.8 (Hansen et al. 1997). Grazing 
of the heterotrophs was calculated from the production rates, assuming a growth efficiency of $33 \%$ (Hansen et al. 1997).

Metazooplankton composition and biomass

Metazooplankton samples were stored in buffered formalin (4\% vol. final concentration). Aliquots were subsampled using a Motoda splitter and counted in a Bogorov tray using a Nikon SMZ 1000 stereomicroscope. At magnification $\times 8$ to $\times 80$, copepods and meroplankton larvae were identified to genus or species level and enumerated. Calanoid and cyclopoid nauplii were discriminated according to their size and morphology (Gibbons and Ogilvie 1933; Ogilvie 1953). Prosome length or developmental stages of copepodids and total length of nauplii and meroplankton larvae were determined and abundances converted into carbon biomass following equations chosen from relevant references. For copepodids, Calanus spp. carbon was converted according to Hirche and Mumm (1992), Cyclopoids and other minor orders from Sabatini and Kiørboe (1994, eq. for Oithona similis), Metridia longa from Hanssen (1997), Pseudocalanus spp. from Conover and Huntley (1991), and Microcalanus spp. from Klein Breteler et al. (1982, eq. for P. minutus). Cyclopoid nauplii were converted from Sabatini and Kiørboe (1994), calanoid and cirripeda nauplii from Klein Breteler et al. (1982), and for pluteus and veliger larvae, we used Fotel et al. (1999, eq. for Mytilus edulis). When necessary, ash-free dry weight to dry weight conversion factor was taken from Mauchline (1998) and a carbon weight to dry weight ratio of 0.473 was used (Conover and Huntley 1991).

\section{Statistical analyses}

A multiple linear regression analysis (Systat $12^{\circledR}$ ) was conducted to evaluate whether in situ water temperature or bulk food concentration (total Chl $a$, Chl $a>10 \mu \mathrm{m}$, POC) explained best the observed variance in heterotrophic ciliate and dinoflagellate biomass. All biomass values were log-transformed to account for non-normal distribution. With help of stepwise backward elimination, all potential explanatory variables that fell below the $5 \%$ significance level were excluded.

\section{Results}

\section{Hydrography}

In late January to early March 2006, an oceanographic mooring in the outer basin of Kongsfjorden recorded a strong inflow of Atlantic water (Cottier et al. 2007). In concert with a period of intense atmospheric cooling in the fjord, a homogenous water column of $0.6 \pm 0.1^{\circ} \mathrm{C}$ and salinity of $34.7 \pm 0.2$ were formed in March 2006 (Fig. 2). In April, the water temperature remained low $\left(0.6 \pm 0.1^{\circ} \mathrm{C}\right)$, but showed a weak pycnocline at approximately $30 \mathrm{~m}$. Surface water temperature increased to $2^{\circ} \mathrm{C}$ in May and reached temperatures of $3-6^{\circ} \mathrm{C}$ in July and September. A minor inflow of Atlantic water was recorded by the oceanographic mooring at depth in mid-May, while a major inflow took place in mid-July (pers. comm. F. Cottier). From the time of the snow-melt (May/June) and onwards, the fjord was influenced by freshwater run-off from glaciers and land, resulting in a shallow stratified water column (approximately $10 \mathrm{~m}$ in July and $30 \mathrm{~m}$ in September) with surface water salinity of $33.8 \pm 0.9$ (July/September, Fig. 2). In December, the water had been cooled down to $1.5^{\circ} \mathrm{C}$ and formed a homogenous body with a salinity of $34.6 \pm 0.02$. The depth of the euphotic zone ranged between $0 \mathrm{~m}$ (December) to $40 \mathrm{~m}$ (March), and intermediate depths of 12
Fig. 2 Hydrographical profiles of temperature $\left({ }^{\circ} \mathrm{C}\right.$; stippled line), salinity (broken line), and density $\left(\mathrm{kg} \mathrm{m}^{-3}\right.$; solid line $)$ of the upper $100 \mathrm{~m}$ of the water column at station KB3 for the different months of sampling. The horizontal line indicates the depth of the biological sampling programme $(0-50 \mathrm{~m})$

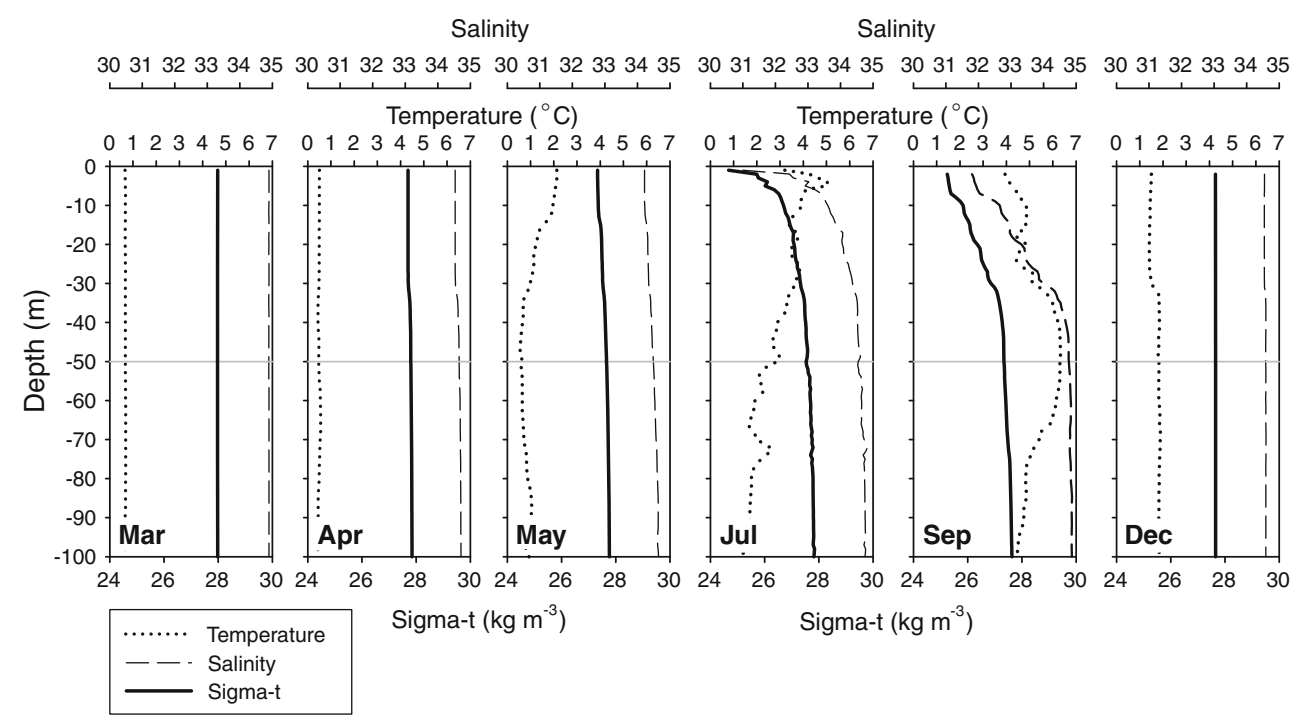


and $18 \mathrm{~m}$ in April and May, respectively (pers. comm. E. Nøst Hegseth).

Seasonal abundance and composition of protists

The spring phytoplankton bloom developed in April (Fig. 3a, b). Chl $a$ concentration increased from 0.02 to $10 \mu \mathrm{g}$ Chl $a 1^{-1}$ from March to April, respectively (Fig. 3a). In April, 70\% of the Chl $a$ was in the $>10 \mu \mathrm{m}$ size class (Rokkan Iversen and Seuthe accepted), reflecting the high abundance of larger diatoms (Fig. 3b). The importance of large $(>10 \mu \mathrm{m})$ phytoplankton decreased to only $5 \%$ of the total $\mathrm{Chl} a$ during summer, when pico- and nano-sized phototrophs dominated the phytoplankton (Rokkan Iversen and Seuthe accepted). Centric diatoms showed a small second increase in abundance in September (Fig. 3b). Pico- and nano-sized heterotrophs were most abundant in July and September (Rokkan Iversen and Seuthe accepted; our Table 4).

The seasonal abundance of ciliates and dinoflagellates mimicked the distribution of phytoplankton, with highest abundance in April (Fig. 3c-e). Ciliates reached peak abundance with up to $3.5 \times 10^{3}$ cells $1^{-1}$ in April, while their abundance was lower by a factor of ten during the other seasons (Fig. 3c). Dinoflagellates were more abundant than ciliates, with a highest total abundance of $54 \times 10^{3}$ cells $1^{-1}$ in April. In general, small dinoflagellates $(\mathrm{ESD}<20 \mu \mathrm{m})$ constituted the largest bulk of total dinoflagellate abundance (60-99\%, Fig. 3d, e).

Numerically, aloricate forms dominated the ciliate assemblage with $>80 \%$, except in September when aloricate and loricate forms were equally abundant (Table 1). In March, aloricate ciliates were dominated by $M$. rubra and holotrich ciliates with 44 and $42 \%$, respectively. Strombidiids became with $>90 \%$, the most important aloricate ciliate group in April, May, and July. Their contribution to total aloricate numbers decreased in September to $<70 \%$, when strobilidiids became more abundant. Dinoflagellates were numerically dominated by athecate forms at all times (Table 1). Predominant athecate genera were Gymnodinium and Gyrodinium, except in March when also species of Amphidinium were present.

Biomass of heterotrophic ciliates and dinoflagellates

A large fraction of the ciliates' and dinoflagellates' biomass was constituted of chloroplast-bearing species, especially in April, May, and July (Fig. 4; Table 1). Plastidic ciliates, such as Myrionecta rubra, Laboea strobila, and Strombidium conicum, contributed with 60 and $70 \%$ to the total ciliate biomass in April and July, respectively (Fig. 4; Table 1). Among dinoflagellates, chloroplast-containing species, such as Heterocapsa triquetra, Scripsiella trochoidea, and
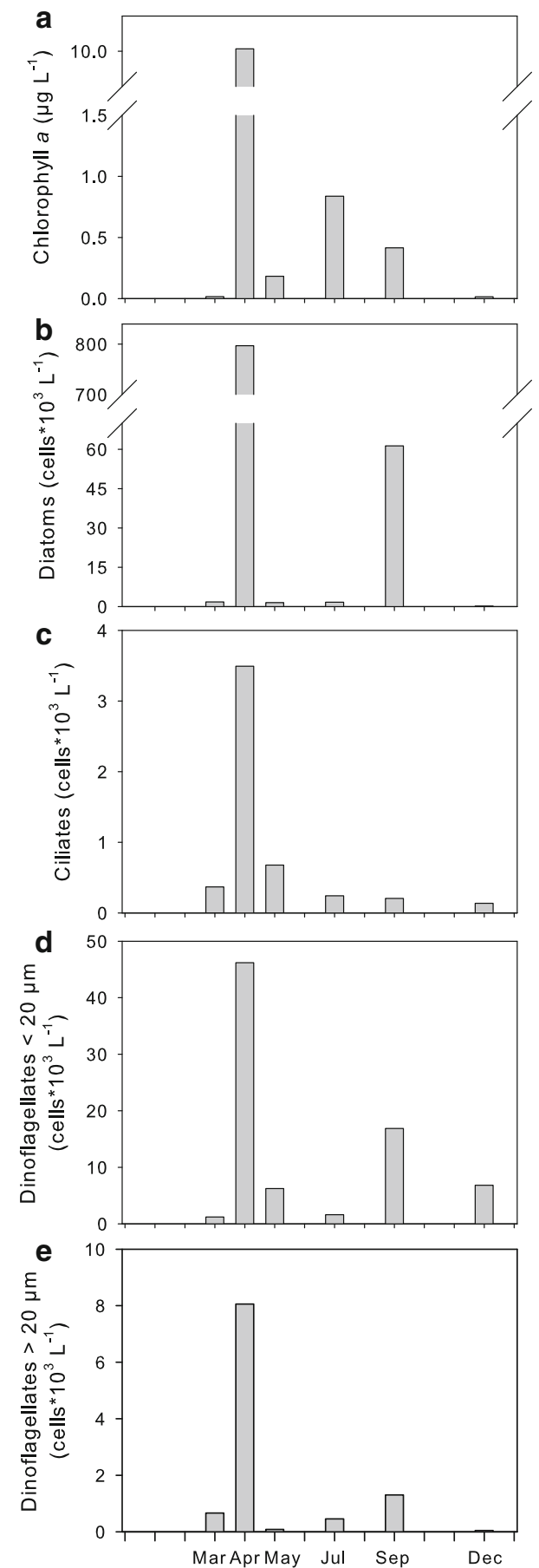

Fig. 3 Average integrated (a) concentration of chlorophyll $a$ ( $\mu \mathrm{g} \mathrm{Chl}$ $a 1^{-1}$ ), and abundance of (b) diatoms (cells $\times 10^{3} 1^{-1}$ ), (c) ciliates $\left(\right.$ cells $\left.\times 10^{3} 1^{-1}\right)$, (d) dinoflagellates $<20 \mu \mathrm{m}\left(\right.$ cells $\left.\times 10^{3} 1^{-1}\right)$, and (e) dinoflagellates $>20 \mu \mathrm{m}$ (cells $\times 10^{3} 1^{-1}$ ) for the upper $50 \mathrm{~m}$ of the water column. Ciliates and dinoflagellate abundance is given as total number, including both plastidic and heterotrophic species. Note the difference in scales

Gymnodinium arcticum, were most dominant in April and May with about $70 \%$ (Fig. 4). The contribution of plastidic ciliates and dinoflagellates decreased considerably in 


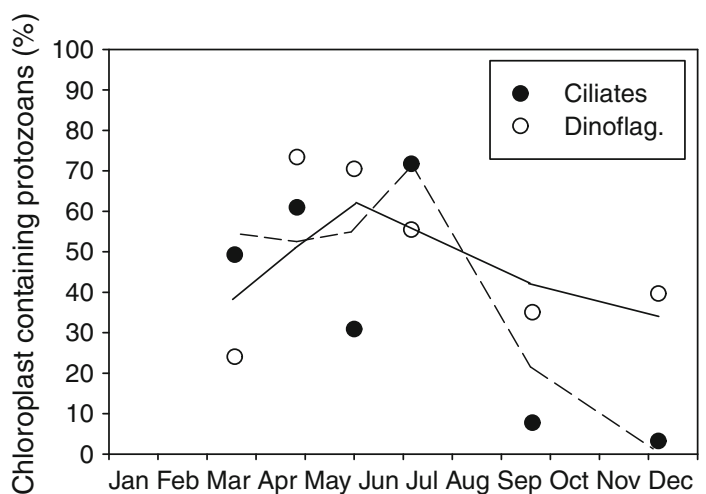

Fig. 4 Percentage $(\%)$ of chloroplast-containing ciliates and dinoflagellates over the year, based on biomass estimates. The trend in the data is visualized by a trend line (LOWLESS smoother, tension $=0.85$, SYSTAT 12), with a stippled line for ciliates and a solid line for dinoflagellates

September and December, with $<10 \%$ in ciliates and about $40 \%$ in dinoflagellates.

The biomass of heterotrophic ciliates exceeded that of heterotrophic dinoflagellates except in April (Fig. 5), when heterotrophic dinoflagellates peaked with $451 \mathrm{mg} \mathrm{C} \mathrm{m}^{-2}$ (compared to a biomass of heterotrophic ciliates of $269 \mathrm{mg}$

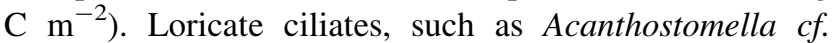
norvegica, Parafavella sp., and Ptychocylis sp., dominated the heterotrophic ciliate biomass except for March and December (Fig. 5; Table 1). Athecate forms dominated the biomass of heterotrophic dinoflagellates except in July, when thecate forms of the genus Protoperidinium dominated the heterotrophic dinoflagellate biomass with $81 \%$ (Fig. 5; Table 1).

\section{Protozooplankton growth rates}

Experimentally determined growth rates of oligotrich ciliates and athecate dinoflagellates ranged from $-0.3 \pm 0.2$ $\mathrm{d}^{-1}$ to $0.8 \pm 0.4 \mathrm{~d}^{-1}$ (Table 2). The seasonal pattern in the daily protozoan production was similar for heterotrophic ciliates and dinoflagellates (Fig. 5). It peaked for both protozoan groups in April (52 and $85 \mathrm{mg} \mathrm{C} \mathrm{m}^{-2} \mathrm{~d}^{-1}$ for heterotrophic ciliates and dinoflagellates, respectively) and was lowest in March and December. Ciliate production was negative in March.

\section{Metazooplankton}

Metazooplankton composition, abundance, and biomass were highly variable across seasons (Fig. 6). Variations in total abundance were essentially due to larval forms (i.e., copepod nauplii and meroplankton larvae) and showed a considerable maximum in May $\left(5.6 \times 10^{3}\right.$ ind. $\left.\mathrm{m}^{-3}\right)$. Total biomass changed by an order of magnitude over time, from about $2.5 \mathrm{~g} \mathrm{C} \mathrm{m}^{-2}$ in March and May to $0.24 \mathrm{~g} \mathrm{C} \mathrm{m}^{-2}$ in

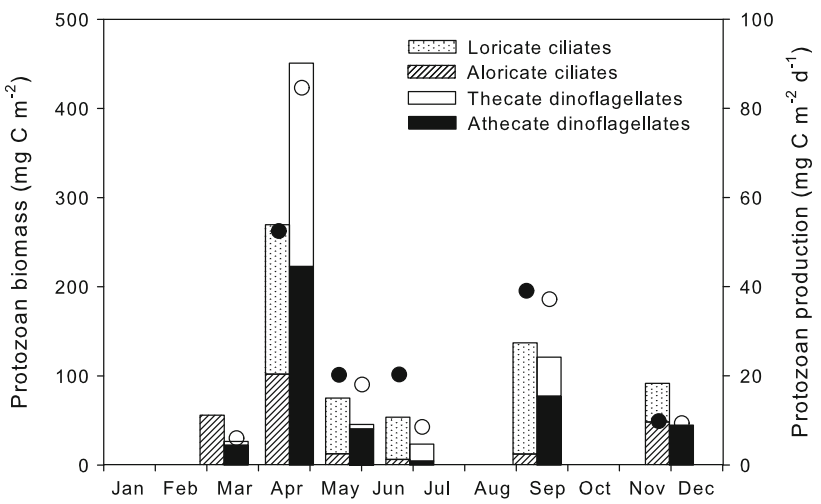

Fig. 5 Biomass (left axis: $\mathrm{mg} \mathrm{C} \mathrm{m}^{-2}$; bars) of heterotrophic dinoflagellates and ciliates integrated for the upper $50 \mathrm{~m}$ of the water column. Calculated integrated community growth (right axis: $\mathrm{mg} \mathrm{C}$ $\mathrm{m}^{-2} \mathrm{~d}^{-1}$ ) for heterotrophic dinoflagellates (athecate and thecate; open circles) and heterotrophic ciliates (aloricate and loricate; filled circles) is given

December. In April, the metazooplankton biomass was $0.9 \mathrm{~g} \mathrm{C} \mathrm{m}^{-2}$ and consequently much lower than in March and May. Large copepodids dominated overall the community biomass, exceeding $90 \%$ in March, July, and September, but their contribution was as low as $40 \%$ in April and May. Large copepodids (stages IV-VI) of Metridia spp. were responsible for the very high biomass in March. Apart from March, large copepodids consisted almost exclusively of Calanus glacialis and C. finmarchicus.

The small copepod fraction $(\leq 1 \mathrm{~mm})$ consisted of cyclopoid and calanoid nauplii, as well as copepodids from small species. They represented 70-99\% of total copepod abundance and 23-41\% in terms of biomass in April, May, and December, but only 4-6\% of biomass in March, July, and September. Copepod nauplii had a peak in abundance and biomass in May $\left(2.4 \times 10^{3}\right.$ ind. $\mathrm{m}^{-3}$ and $0.22 \mathrm{~g} \mathrm{C}$ $\mathrm{m}^{-2}$, respectively), and cyclopoid nauplii were observed at all seasons. Small copepodid abundance was fairly stable over the year $\left(0.22-0.54 \times 10^{3}\right.$ ind. $\left.\mathrm{m}^{-3}\right)$, and the biomass was maximal in April $\left(0.21 \mathrm{~g} \mathrm{C} \mathrm{m}^{-2}\right)$, earlier than for copepodids of larger species. Among small copepodids, Oithona similis was a major component from May to December (54-85\% in abundance; $13-63 \%$ in biomass). Pseudocalanus spp. showed an increased importance in April and July, whereas during March and December, Microcalanus spp., Oncaeidae, and three other orders (Harpactoida, Monstrilloida, and Mormonilloida) were significant contributors.

Meroplankton larvae were present in spring and summer only and consisted of cirripede nauplii in late spring (tripling from late April to late May, up to $1.2 \times 10^{3}$ ind. $\mathrm{m}^{-3}$ ). Towards summer, veliger and pluteus larvae (about. $1.2 \times 10^{3}$ ind. $\mathrm{m}^{-3}$ and $0.1-0.2 \times 10^{3}$ ind. $\mathrm{m}^{-3}$ from late May to July) appeared. The meroplankton biomass 
Table 2 Experimentally determined growth rates $\mu$ (average \pm standard deviation; $\mathrm{d}^{-1}$ ) of heterotrophic ciliates and dinoflagellates at $2 \pm 1{ }^{\circ} \mathrm{C}$ (March, April, May) and $4 \pm 1^{\circ} \mathrm{C}$ (July, September)

\begin{tabular}{|c|c|c|c|c|c|c|c|}
\hline \multirow[t]{2}{*}{ Group } & \multirow{2}{*}{$\begin{array}{l}\text { ESD } \\
(\mu \mathrm{m})\end{array}$} & \multirow{2}{*}{$\begin{array}{l}\text { Vol. } \\
\left(\mu \mathrm{m}^{3}\right)\end{array}$} & \multicolumn{5}{|c|}{ Growth rate $\mu\left(\mathrm{d}^{-1}\right)$} \\
\hline & & & March & April & May & July & September \\
\hline \multicolumn{8}{|l|}{ Ciliates } \\
\hline Holotrichs & & 416 & $-0.270 \pm 0.182$ & & & & \\
\hline \multirow[t]{3}{*}{ Oligotrichs $^{\mathrm{a}}$} & $10-20$ & 2,671 & $-0.072 \pm 0.141$ & $0.219 \pm 0.094$ & $0.318 \pm 0.152$ & $0.754 \pm 0.514$ & $-0.051 \pm 0.095$ \\
\hline & $20-30$ & 9,000 & & $0.537 \pm 0.110$ & & & \\
\hline & $>40$ & 56,250 & & $0.096 \pm 0.039$ & & & \\
\hline \multicolumn{8}{|l|}{ Dinoflagellates } \\
\hline Protoperidinium spp. & & 2,000 & & $0.275 \pm 0.127$ & & & $0.367 \pm 0.292$ \\
\hline \multirow[t]{2}{*}{ Athecates ${ }^{\mathrm{b}}$} & $10-20$ & 2,220 & $0.259 \pm 0.260$ & $-0.026 \pm 0.376$ & $0.244 \pm 0.209$ & $0.796 \pm 0.399$ & $0.211 \pm 0.134$ \\
\hline & $20-30$ & 8,860 & & $0.278 \pm 0.164$ & $0.716 \pm 0.500$ & & \\
\hline
\end{tabular}

${ }^{a}$ Dominated by Strombidium spp.

${ }^{\mathrm{b}}$ Dominated by Gymnodinium spp. and Gyrodinium spp.
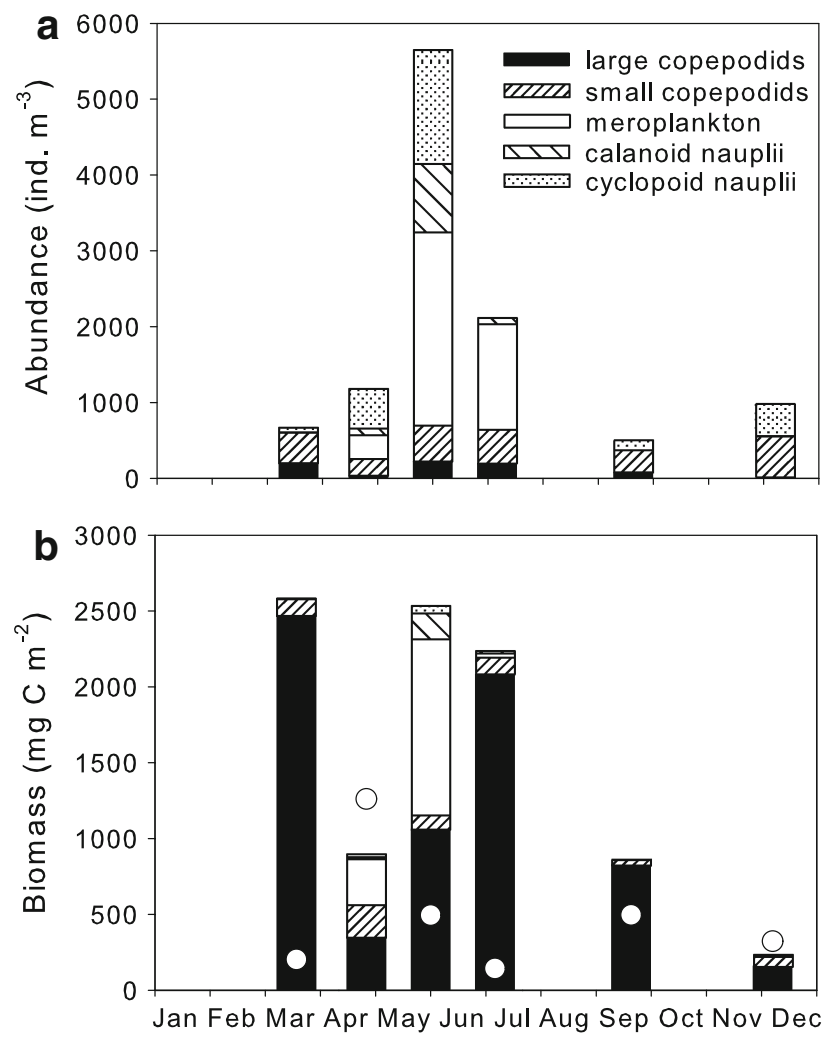

Fig. 6 Contribution of different developmental stages and size groups to the total metazooplankton (a) abundance $\left(10^{3}\right.$ ind. $\left.\mathrm{m}^{-2}\right)$ and (b) biomass (mg C m${ }^{-2}$; bars), integrated for 200-0 m. For comparison, protozoan biomass is given ( $\mathrm{mg} \mathrm{C} \mathrm{m}^{-2}$; open circles), integrated for the upper $200 \mathrm{~m}$ of the water column by using trapezoidal integration of the measured biomass at $50 \mathrm{~m}$ to an assumed biomass of zero at $200 \mathrm{~m}$

contribution relied essentially on cirripede nauplii and was maximal in May $\left(1.2 \mathrm{~g} \mathrm{C} \mathrm{m}^{-2}\right)$.

Protozooplankton (heterotrophic ciliate and dinoflagellate) biomass exceeded that of metazooplankton in April and December with a factor of 1.4 and 1.3 , respectively (Fig. 6b), but was otherwise lower by a factor of $<0.6$.

\section{Discussion}

Biomass and taxonomic composition of protoand metazooplankton

The total ciliate and dinoflagellate assemblage in Kongsfjorden was numerically dominated by aloricate ciliates, such as Strombidium spp., and athecate dinoflagellates of the genera Gymnodinium and Gyrodinium (Table 1), as reported from other marine ecosystems (Tillmann and Hesse 1998; Levinsen and Nielsen 2002; Sherr et al. 2009). In the purely heterotrophic fraction of the assemblage in Kongsfjorden, loricate ciliates were dominating. However, the contribution of loricate ciliates would have been significantly smaller if mixotrophic species, such as Laboea strobila and Strombidium conicum, would have been taken into account as part of the phagotrophic plankton, as done in other studies (e.g., Levinsen and Nielsen 2002). The biomass of heterotrophic ciliates and dinoflagellates observed in Kongsfjorden showed largely the same range as reported from other subarctic and arctic areas (Table 3).

In contrast to other Arctic systems, where heterotrophic dinoflagellates generally account for over half of the total protozooplankton biomass (Levinsen and Nielsen 2002; Sherr et al. 2009), ciliates dominated the protozooplankton in Kongsfjorden at most times (Fig. 5). These results are, however, heavily dependent on the classification of dinoflagellates (heterotrophic or phototrophic). In the present study, dinoflagellates were classified according to the description of chloroplasts of a given species in the literature. Thus, e.g., Heterocapsa triquetra was classified 
Table 3 Mean standing stocks ( $\mu \mathrm{g} \mathrm{C}^{-1}$ ) of heterotrophic ciliates, dino-, and nanoflagellates (Dino. and Flag.) reported from different subarctic and arctic areas

\begin{tabular}{|c|c|c|c|c|c|c|}
\hline \multirow[t]{2}{*}{ Region } & \multirow[t]{2}{*}{ Months } & \multirow[t]{2}{*}{ Depth } & \multicolumn{3}{|c|}{ Biomass $\left(\mu \mathrm{g} \mathrm{C} 1^{-1}\right)$} & \multirow[t]{2}{*}{ References } \\
\hline & & & Ciliates & Dino. & Flag. & \\
\hline \multirow[t]{2}{*}{ Kongsfjorden } & Mar-Dec & $0-50$ & $1-5$ & $0.5-9$ & & This study \\
\hline & Mar-Dec & & & & $0.1-11$ & Rokkan Iversen and Seuthe (accepted) \\
\hline Norwegian fjord & April & $0-120$ & 18 & 17 & 23 & Archer et al. (2000) \\
\hline \multirow[t]{4}{*}{ Barents Sea } & Jun-Jul & 1 & $3-9$ & $4-10$ & $3-10$ & Verity et al. (2002) \\
\hline & May & $0-100$ & $\leq 8^{\mathrm{a}}$ & $\leq 34^{\mathrm{a}}$ & & Jensen and Hansen (2000) \\
\hline & May & $0-60$ & $\leq 24^{\mathrm{b}}$ & $\leq 35^{\mathrm{b}}$ & $\leq 14^{\mathrm{b}}$ & Hansen et al. (1996) \\
\hline & Mar-Jul & $0-90$ & $\leq 18^{\mathrm{c}}$ & $0.1-9$ & $3-120^{\mathrm{d}}$ & Ratkova and Wassmann (2002) \\
\hline Greenland Sea & Aug-Sep & $0-100$ & $0.1-20$ & & & Antia (1991) \\
\hline Fram Strait & Jun & $0-100$ & $0.2-17$ & & & Auf dem Venne (1994) \\
\hline NE Greenland fjord & Jun-Aug & $0-35$ & $0.6-4$ & $0.6-2$ & & Rysgaard et al. (1999) \\
\hline \multirow[t]{4}{*}{ W Greenland } & Jul-Sep & $0-30$ & $5-24$ & $2-32$ & & Levinsen et al. (1999) \\
\hline & 14 months & $0-200$ & $<0.1-4$ & $<0.1-6$ & & Levinsen et al. (2000) \\
\hline & Mar-May & $1+15$ & $<1-6$ & $<1-20$ & & Madsen et al. (2008) \\
\hline & Jun-Jul & $0-30$ & $7-20$ & $10-16$ & $2-5$ & Nielsen and Hansen (1995) \\
\hline \multirow[t]{2}{*}{ Franklin Bay } & Dec-Mar & 0 & 0.3 & & 2 & Vaqué et al. (2008) \\
\hline & Mar-May & & 0.4 & & 4 & \\
\hline Canada Basin/Chuckchi Sea & May-Aug & Chl max & $0.5-25$ & $0.8-53$ & & Sherr et al. (2009) \\
\hline Gulf of Alaska & May-Sep & $0-80$ & $2-6$ & $0.6-3$ & $2-10$ & Booth et al. (1993) \\
\hline SE Bering Sea & Apr & $0-70$ & $0.1-5$ & $0.2-5$ & & Howell-Kübler et al. (1996) \\
\hline Arctic Ocean (Makarov Basin) & Aug & $0-25$ & $\leq 5$ & $\leq 9$ & $\leq 38^{\mathrm{e}}$ & Olli et al. (2007) \\
\hline
\end{tabular}

The biomasses are the integrated mean over the given depth ranges or concentrations of single depths $(\mathrm{m})$

${ }^{a}$ Maximum biomass values estimated from Fig. 4

b Maximum biomass values estimated from Fig. 3

c Value estimated from Fig. 6

${ }^{\mathrm{d}}$ Calculated from Table 4 taking cryptophytes, chrysophytes, and choanoflagellates into account

e Calculated from Table 3 taking cryptophytes, chrysophytes, prymnesiophytes, and zoomastigophores into account

Table 4 Integrated biomass $(0-50 \mathrm{~m})$ of heterotrophic protozooplankton (pico-, nano-, and microprotozooplankton), and the contribution of the different size groups (in percentage, \%) in Kongsfjorden in 2006

\begin{tabular}{|c|c|c|c|c|c|}
\hline \multirow[t]{2}{*}{ Month } & \multirow{2}{*}{$\begin{array}{l}\text { Protozoooplankton } \\
\left(\mathrm{mg} \mathrm{C} \mathrm{m}^{-2}\right)\end{array}$} & \multicolumn{4}{|c|}{ Proportion of total protozooplankton biomass (\%) } \\
\hline & & Picoplankton & Nanoflagellates & Dinoflagellates & Ciliates \\
\hline Mar & 89 & 0.1 & 7 & 30 & 63 \\
\hline Apr & 796 & $<0.1$ & 9 & 57 & 34 \\
\hline May & 132 & 0.1 & 8 & 35 & 57 \\
\hline Jul & 635 & 0.4 & 87 & 4 & 8 \\
\hline Sep & 323 & 0.1 & 20 & 38 & 42 \\
\hline Dec & 161 & 0.1 & 15 & 28 & 57 \\
\hline
\end{tabular}

Biomass values on heterotrophic pico- and nanoplankton are taken from Rokkan Iversen and Seuthe (accepted)

as phototroph (Thomas 1997). This species has, however, been observed to ingest fluorescently labelled algae (Legrand et al. 1998). Similarly, food vacuoles have been noticed in Scripsiella sp. (Jacobsen and Anderson 1996), another species here excluded from the biomass of heterotrophic dinoflagellates. Consequently, the contribution of heterotrophic dinoflagellates to the total protozooplankton biomass may have been underestimated in the present study. Interestingly, heterotrophic dinoflagellates contributed more to the total protozooplankton biomass in April and September (Fig. 5; Table 4) when diatoms were abundant (Fig. 3b), mirroring the ability of dinoflagellates 
to efficiently feed on large-celled phytoplankton (Hansen 1991; Sherr and Sherr 2007).

Combined reports on heterotrophic ciliate, dinoflagellate, and nanoflagellate biomasses from Arctic areas are scarce (Table 3), but where all three groups were investigated simultaneously, their biomasses were either of the same magnitude (Booth et al. 1993; Verity et al. 2002) or the biomass of ciliates and dinoflagellates dominated over that of nanoflagellates (Nielsen and Hansen 1995). Where nanoflagellates were reported to dominate the protozooplankton biomass, the system appeared to be in a low productive state, e.g., under the land-fast ice in winterspring (Vaqué et al. 2008), or the central Arctic Ocean (Olli et al. 2007). In Kongsfjorden, heterotrophic ciliates and dinoflagellates greatly dominated the total protozooplankton biomass at all times, except in July when heterotrophic nanoflagellates constituted $87 \%$ of the total protozooplankton biomass (Table 4), coinciding with high abundances of phototrophic picoplankton (Rokkan Iversen and Seuthe accepted).

The metazooplankton biomass was in the range reported previously from Kongsfjorden during summer (Hop et al. 2002). As characteristic for arctic and subarctic copepod communities, the metazooplankton was dominated by small copepods, such as Oithona similis, in terms of numbers, while large calanoid copepods, such as Calanus spp., dominated the zooplankton biomass (Arashkevich et al. 2002; Ashjian et al. 2003; Hopcroft et al. 2005). As typical for shallow coastal Arctic waters (Turner et al. 2001) and shelf seas (Pasternak et al. 2008), high abundance and biomass of meroplankton added a strong seasonal signal to the metazooplankton assemblage. In addition, copepod nauplii exhibited high abundance in May, which is in accordance with earlier reports from Kongsfjorden (Lischka and Hagen 2005).

Proto- and metazooplankton composition and biomass in Kongsfjorden thus did not differ profoundly from those of other Arctic ecosystems and heterotrophic ciliates and dinoflagellates dominated over heterotrophic flagellates at most times.

Growth and potential bottom-up control of protozooplankton

The experimentally determined growth rates of heterotrophic ciliates and dinoflagellates in Kongsfjorden (Table 2) were within the range reported previously from cold waters (Levinsen et al. 1999; Hansen and Jensen 2000; Møller et al. 2006). In March, positive growth was only observed for heterotrophic athecate dinoflagellates in the size class $10-20 \mu \mathrm{m}$, while heterotrophic ciliates decreased in abundance in the incubation bottles over time. Negative growth rates were reported previously in similar experiments and have been argued to reflect trophic interactions between protozooplankton, with dinoflagellates most likely preying on ciliates (Hansen et al. 1999; Møller et al. 2006). Predation by dinoflagellates on ciliates may have constituted a possible source of nutrition in the relatively food-poor environment in March.

Concentrations of food thresholds have been discussed for heterotrophic ciliates and dinoflagellates in the literature, but divert greatly between species (e.g., Jakobsen and Hansen 1997; Gismervik 2005). In a recent review of culture-based growth studies, Sherr and Sherr (2009) found maximal growth rates of heterotrophic ciliates and dinoflagellates reduced by $50 \%$ at food concentrations of $0.25-5 \mu \mathrm{g} \mathrm{Chl} a 1^{-1}$ and to be zero at $0.1-2 \mu \mathrm{g} \mathrm{Chl} a 1^{-1}$. According to these thresholds, no growth of heterotrophic ciliates and dinoflagellates should have occurred in Kongsfjorden in March and December, when Chl $a$ concentrations were $<0.1 \mu \mathrm{g}^{-1}$ (Fig. 3a). The persistence and even low growth of protozooplankton in similar food-poor conditions have been related to possible patches of higher food concentration, which are successfully detected and exploited by protozoans (Jakobsen and Hansen 1997; Paffenhofer et al. 2007). Interestingly in March, the encountered ciliate assemblage consisted almost exclusively of holotrichs and Myrionecta rubra (Table 1). Holotrich ciliates have been observed to be bactivorous in low-productive environments (Sime-Ngando et al. 1999), and $M$. rubra depends on very low prey abundance to retrieve chloroplasts for its phototrophic mode (Smith and Hansen 2007). It thus appears that the scarcity of potential food in March selected for certain groups of ciliates.

Growth rates by heterotrophic ciliates and dinoflagellates were largely enhanced in spring and summer (Table 2), when Chl $a$ concentrations had increased by a factor of 11-615 (Fig. 3a). Both ciliates and dinoflagellates prey on a large variety of food, depending on own cell size and feeding strategy (Pierce and Turner 1992; Jeong 1999). In general, ciliates are thought to have a narrower predatorsize to prey-size ratio than dinoflagellates (Hansen et al. 1994). Tintinnids, which dominated the heterotrophic ciliate biomass in Kongsfjorden, have been described to consume primarily nano-sized $(2-20 \mu \mathrm{m})$ prey, while the aloricate-dominating oligotrichous ciliates mainly graze on cells $<10 \mu \mathrm{m}$ (Pierce and Turner 1992, and references therein). Nevertheless, ciliates have also been observed to feed on diatoms (Aberle et al. 2007). Consequently, ciliates should have encountered a rich grazing ground in Kongsfjorden from April onwards, when pico- and nanoplankton were highly abundant (Rokkan Iversen and Seuthe accepted). The ability of many dinoflagellates to efficiently graze on diatoms was reflected in their co-occurrence with elevated diatom abundances in Kongsfjorden in April and September. Especially the pallium-feeding thecate 
Protoperidinium spp. showed increased abundance in conjunction with diatoms (Table 1), as seen previously in other marine systems (e.g., Hansen 1991; Sherr and Sherr 2007). Athecate dinoflagellates, such as the dominating Gymnodinium spp. and Gryrodinium spp., also responded to the increased abundance of large phytoplankton in April and September. However, due to their feeding strategy by direct engulfment of prey, these protozoans are able to feed on a larger prey-size spectrum (Jeong 1999), which was mirrored in their more even abundance throughout the year (Table 1).

Heterotrophic ciliates and dinoflagellates in Kongsfjorden thus appeared to have been controlled by food concentration in March and December, while adequate food should have been available from the spring bloom onwards. Consistently, the variance in protozooplankton biomass observed in Kongsfjorden over the year was best explained by food concentration, such as total Chl $a$ for ciliates (multiple linear regression: $F_{1,34}=27.568, P<0.001$, $r^{2}=0.448$ ) and Chl $a>10 \mu \mathrm{m}$ for dinoflagellates (multiple linear regression: $F_{1,34}=57.655, P<0.001, r^{2}=$ 0.629), rather than in situ temperature. Consequently, other controlling mechanisms must have acted during the other times, when prey availability was high but heterotrophic ciliate and dinoflagellate abundance was low.

Potential top-down control of the protozoan stock by copepods

The large calanoid copepods, Calanus spp., are known to prey on protozooplankton (Levinsen et al. 2000; Campbell et al. 2009), making them apparent candidates for controlling ciliate and dinoflagellate stocks due to their high biomass and ingestion rates. Calanus hyperboreus, for instance, accounted for a daily loss of the protozoan stock of 5-6\% in the Greenland Sea (Antia 1991). A suite of studies also reported C. finmarchicus (Ohman and Runge 1994; Nejstgaard et al. 1997; Irigoien et al. 1998) and C. glacialis (Campbell et al. 2009) to select positively for ciliates. However, large seasonal and individual variations in the contribution of protozoan to the copepods diet prevail (Koski and Wexels Riser 2006; Castellani et al. 2008; Campbell et al. 2009). For example, most of the daily ingestion of $C$. finmarchicus consisted of protozooplankton during a post-bloom scenario in Disko Bay (Greenland), while this diet component was negligible during the early phase of a phytoplankton bloom (Levinsen et al. 2000).

Levinsen et al. (2000) reported clearance rates of Calanus spp. of 1 and $4 \mathrm{ml}(\mu \mathrm{g} \mathrm{C})^{-1} \mathrm{~d}^{-1}$ on ciliates of ESD 15 and $50 \mu \mathrm{m}$, respectively, and 0.5 and $2 \mathrm{ml}(\mu \mathrm{g} \mathrm{C})^{-1} \mathrm{~d}^{-1}$ on dinoflagellates ESD 15 and $50 \mu \mathrm{m}$, respectively. Calculations of the potential grazing impact of $C$. finmarchicus and $C$. glacialis on heterotrophic ciliates and dinoflagellates in Kongsfjorden, applying these literature values and correcting for temperature with a $Q_{10}$ of 2.8 (Hansen et al. 1997), revealed a different scenarios during the spring bloom and the post-bloom summer situation. In April, the calculated daily Calanus ingestion was 3 and 19 times lower than that of daily heterotrophic ciliate and dinoflagellate production, respectively. Since the clearance rates of Calanus on protozoans seem to decrease during rich phytoplankton blooms (Levinsen et al. 2000), these calculations most likely even overestimate the grazing impact during spring. Therefore, the two Calanus species exerted little or no control on the protozoan stock in Kongsfjorden in April. At the same time, small omnivorous calanoid copepods, such as Pseudocalanus sp., constituted equally in biomass and may have contributed to the grazing on protozoans by their higher specific grazing rates (Levinsen et al. 2000; Campbell et al. 2009). In the period after the spring bloom (May, July, and September), Calanus spp. daily ingestion of dinoflagellates never accounted for $>10 \%$ of the daily dinoflagellate production, but the ingestion of ciliates exceeded their heterotrophic production in July. Moreover, also the ubiquitous small copepods Oithona similis and Pseudocalanus spp. (Møller et al. 2006; Castellani et al. 2008), as well as the periodically highly abundant copepod and cirripede nauplii (Turner et al. 2001), are known to prey on ciliates and dinoflagellates. Consequently, metazooplankton may well have had a controlling impact on the protozoan stock during the post-bloom period in Kongsfjorden.

Due to the great plasticity in behaviour and prey selectivity of copepods, calculations of the possible grazing impact by copepods from literature values have to be interpreted with caution. It is, however, striking that the maximum protozoan biomass in our data set occurred in concert with a low abundance of large copepods and a two times lower metazooplankton biomass compared to May and July. In April, heterotrophic ciliates and dinoflagellates dominated the total zooplankton (protozoan and metazoan) biomass (58\%, Fig. 6b). During the post-bloom period, also the structure of the food web indicated that top-down control was an important controlling factor for the protozoan assemblage. This was suggested by (a) low abundances of large protozoan despite high abundances of their flagellate prey and (b) high concentrations of metazooplankton and large calanoid copepods at times when $>70 \%$ of the Chl $a$ was in the size fraction $<10 \mu \mathrm{m}$ (Rokkan Iversen and Seuthe accepted) and therefore unavailable to a large fraction of the metazooplankton. Thus, especially during the post-bloom period, the structure of the protozoan assemblage must have partly been dependent on dynamics of the metazooplankton. 
Protozooplankton regulation and potential grazing impact

In Disko Bay, western Greenland, Levinsen and Nielsen (2002) attributed high biomasses of protozooplankton to periods with low predation by copepods, either because copepods were satiate by phytoplankton (i.e., during the spring bloom) or because copepods were absent from the euphotic zone (as in late summer after the descend of Calanus spp. to overwintering depths). The authors suggested that heterotrophic ciliates and dinoflagellates should be important grazers in all arctic ecosystems, where protozoan can escape the grazing pressure in periods. In Kongsfjorden, the time of the phytoplankton spring bloom must have been a period of reduced top-down control for ciliates and dinoflagellates, due to moderate abundance of large copepods in conjunction with high concentration of phytoplanktonic food. The protozooplankton could thus build up a significant biomass in concurrence with the spring phytoplankton bloom in April.

Calculations of the potential grazing rate of heterotrophic ciliates and dinoflagellates from their likely daily production (Fig. 5), assuming a gross growth efficiency of $33 \%$ (Hansen et al. 1997), indicated that protozooplankton could have grazed equivalent to $100 \%$ of the daily primary production in April. This calculation assumed complete algaevory, which most probably does not reflect the true composition of the diet of ciliates and dinoflagellates. Nevertheless, it illustrates the great potential of protozooplankton to cycle a significant fraction of primary production even under phytoplankton bloom conditions. The higher biomass of protozooplankton compared to metazooplankton in April, in combination with an order of magnitude greater specific ingestion rates of protozoans than copepods (Hansen et al. 1997 and references therein), suggests further that heterotrophic ciliates and dinoflagellates were the principal grazers in Kongsfjorden under these conditions. In the post-bloom period, the potential grazing impact of protozooplankton was reduced to $26 \%$ (May) and $56 \%$ (July) of the daily primary production. At this time, picoplankton and nanoflagellates dominated the phytoplankton (Rokkan Iversen and Seuthe accepted), and thus a large fraction of primary producers may have been too small for copepods to utilize directly. Under these conditions, heterotrophic ciliates and dinoflagellates may have constituted an important trophic link between microbial primary producers and the larger copepods.

\section{Conclusion}

The present study demonstrates that ciliates and dinoflagellates were an important component of the pelagic food web in Kongsfjorden and did not differ in their biomass from other Arctic and subpolar regions. Food availability may have limited heterotrophic ciliates and dinoflagellates in March and December, while predation by copepods was most probably the controlling factor on the protozoan community in May, July, and September. High biomass of heterotrophic ciliates and dinoflagellates was observed in April during the phytoplankton spring bloom, coinciding with moderate abundance of large copepods. The observed regulatory mechanisms of the protozooplankton community in Kongsfjorden thus did not differ from those in other regions. The importance of the protozooplankton in the pelagic food web of Kongsfjorden was reflected in the calculated potential grazing impact of the protozoan community, which suggested a strong control of the phytoplankton by heterotrophic ciliates and dinoflagellates. Consequently, ciliates and dinoflagellates need to be taken into account when discussing the fate of phytoplankton and biogeochemical cycling in Arctic marine ecosystems.

Acknowledgments We wish to thank the crews on RV Jan Mayen and RV Lance, as well as the staff at the Marine Laboratory and Kings Bay Company in Ny Ålesund. Special thanks to J. Wiktor and T. Ratkova for help with the analyses of the plankton, as well as F. Cottier and E. Nøst Hegseth for hydrographic background information. The map was created with help of the free-ware program Ocean Data View. We are grateful to M. Reigstad and P. Wassmann, as well as three anonymous reviewers for valuable discussions and constructive comments on the manuscript. F. Narcy was supported by a EUR-Oceans scholarship (WP4-SYSAN-1058) and Praceal (IPEV455/IPY-26). The project was funded by Statoil-Hydro in collaboration with the ARCTOS network through the SAARP program (Unit I, a2) and MariClim, funded by the Norwegian Research Council under grant $165112 / \mathrm{s} 30$.

Open Access This article is distributed under the terms of the Creative Commons Attribution Noncommercial License which permits any noncommercial use, distribution, and reproduction in any medium, provided the original author(s) and source are credited.

\section{References}

Aberle N, Lengfellner K, Sommer U (2007) Spring bloom succession, grazing impact and herbivore selectivity of ciliate communities in response to winter warming. Oceanol 150:668-681. doi:10.1007/s00442-006-0540-y

Antia AN (1991) Microzooplankton in the pelagic food web of the East Greenland Sea and its role in sedimentation processes. Dissertation, University of Kiel

Arashkevich E, Wassmann P, Pasternak A, Wexels Riser C (2002) Seasonal and spatial changes in biomass, structure, and development progress of the zooplankton community in the Barents Sea. J Mar Syst 38:125-145

Archer SD, Verity PG, Stefels J (2000) Impact of microzooplankton on the progression and fate of the spring bloom in fjords of northern Norway. Aquat Microb Ecol 22:27-41

Ashjian CJ, Campbell RG, Welch HE, Butler M, Van Keuren D (2003) Annual cycle in abundance, distribution, and size in 
relation to hydrography of important copepod species in the western Arctic Ocean. Deep Sea Res I 50:1235-1261. doi:1210.1016/S0967-0637(1203)00129-00128

Auf dem Venne H (1994) Zur Verbreitung und ökologischen Bedeutung planktischer Ciliaten in zwei verschiedenen Meeresgebieten: Grönlandsee und Ostsee. Dissertation, University of Kiel

Basedow SL, Eiane K, Tverberg V, Spindler M (2004) Advection of zooplankton in an Arctic fjord (Kongsfjorden, Svalbard). Estuar Coast Shelf Sci 60:113-124. doi:110.1016/j.ecss.2003.1012. 1004

Booth BC, Lewin J, Postela JR (1993) Temporal variation in the structure of autotrophic and heterotrophic communities in the subarctic Pacific. Prog Oceanogr 32:57-99. doi:10.1016/00796611(1093)90009-90003

Calbet A, Landry MR (2004) Phytoplankton growth, microzooplankton grazing, and carbon cycling in marine systems. Limnol Oceanogr 49:51-57

Campbell RG, Sherr EB, Ashjian CJ, Plourde S, Sherr BF, Hille V, Stockwell DA (2009) Mesozooplankton prey preference and grazing impact in the western Arctic Ocean. Deep Sea Res II 56:1274-1289. doi:1210.1016/j.dsr1272.2008.1210.1027

Castellani C, Irigoien X, Mayor DJ, Pharris R, Wilson D (2008) Feeding of Calanus finmarchicus and Oithona similis on the microplankton assemblage in the Irminger Sea, North Atlantic. J Plankton Res 30:1095-1116. doi:1010.1093/plankt/fbn1074

Conover RJ, Huntley M (1991) Copepods in ice-covered seasdistribution, adaptations to seasonally limited food, metabolism, growth patterns and life cycle strategies in polar seas. J Mar Syst 2:1-41

Cottier FR, Tverberg V, Inall M, Svendsen H, Nilsen F, Griffiths C (2005) Water mass modification in an Arctic fjord through crossshelf exchange: the seasonal hydrography of Kongsfjorden, Svalbard. J Giophys Res 110:C12005. doi:12010.11029/12004 JC002757

Cottier FR, Nilsen F, Inall M, Gerland S, Tverberg V, Svendsen H (2007) Wintertime warming of an Arctic shelf in response to large-scale atmospheric circulation. Geophys Res Lett 34:L10607. doi:10610.11029/12007GL029948

Fotel FL, Jensen J, Wittrup L, Hansen BW (1999) In situ and laboratory growth by a population of blue mussel larvae (Mytilus edulis L.) from a Danish embayment, Knebel Vig. J Exp Mar Biol Ecol 233:213-230

Gibbons SG, Ogilvie HS (1933) The development stages of Oithona helgolandica and Oithona spinorostris, with a note on the occurrence of body spines in cyclopoid nauplii. J Mar Biol Assoc UK 18:529-550

Gismervik I (2005) Numerical and functional responses of chloreoand oligotrich planktonic ciliates. Aquat Microb Ecol 40:163-173

Hansen PJ (1991) Quantitative importance and trophic role of heterotrophic dinoflagellates in a coastal pelagial food web. Mar Ecol Prog Ser 73:253-261

Hansen PJ, Fenchel T (2006) The bloom-forming ciliate Mesodinium rubrum harbours a single permanent endosymbiont. Mar Biol Res 2:169-177. doi:110.1080/17451000600719577

Hansen BW, Jensen F (2000) Specific growth rates of protozooplankton in the marginal ice zone of the central Barents Sea during spring. J Mar Biol Assoc UK 80:37-44

Hansen BW, Koefoed Bjørnsen P, Hansen PJ (1994) The size ratio between planktonic predators and their prey. Limnol Oceanogr 39:395-403

Hansen BW, Christiansen S, Pedersen G (1996) Plankton dynamics in the marginal ice zone of the central Barents Sea during spring: carbon flow and structure of the grazer food chain. Polar Biol $16: 115-128$
Hansen PJ, Koefoed Bjørnsen P, Hansen BW (1997) Zooplankton grazing and growth: scaling within the $2-2,000 \mu \mathrm{m}$ body size range. Limnol Oceanogr 42:687-704

Hansen BW, Nielsen TG, Levinsen H (1999) Plankton community structure and carbon cycling on the western coast of Greenland during the strtified summer situation: III. Mesozooplankton. Aquat Microb Ecol 16:233-249

Hanssen H (1997) Mesozooplankton of the Laptev Sea and the adjacent eastern Nansen Basin-distribution and community structure in late summer. Rep Polar Res 229:131

Hasle GR, Heimdal BR (1998) The net phytoplankton in Kongsfjorden, Svalbard, July 1988, with general remarks on species composition of arctic phytoplankton. Polar Res 17:31-52

Hirche HJ, Mumm N (1992) Distribution of dominant copepods in the Nansen Basin, Arctic Ocean, in summer. Deep Sea Res I 39:485-505

Hop H, Pearson T, Hegseth EN, Kovacs KM, Wiencke C, Kwasniewski S, Eiane K, Mehlum F, Gulliksen B, WlodarskaKowalczuk M, Cochrane S, Gabrielsen GW, Leakey RJG, Lønne OJ, Zajaczkowski M, Falk-Petersen S, Kendall M, Wangberg S-Å, Bischof K, Voronkov AY, Kovaltchouk NA, Wiktor J, Poltermann M, di Prisco G, Papucci C, Gerland S (2002) The marine ecosystem of Kongsfjorden, Svalbard. Polar Res 21:167-208

Hop H, Falk-Petersen S, Svendsen H, Kwasniewski S, Pavlov V, Pavlova O, Søreide JE (2006) Physical and biological characteristics of the pelagic system across Fram Strait to Kongsfjorden. Prog Oceanogr 71:182-231. doi:110.1016/j.pocean.2006. 1009.1007

Hopcroft RR, Clarke C, Nelson RJ, Raskoff KA (2005) Zooplankton communities of the Arctic's Canada Basin: the contribution by small taxa. Polar Biol 28:198-206. doi:110.1007/s00300-0000400680-00307

Howell-Kübler A, Lessard EJ, Napp JM (1996) Springtime microprotozoan abundance and biomass in the southeastern Bering Sea and Shelikof Strait, Alaska. J Plankton Res 18:731-745

Irigoien X, Head R, Klenke U, Meyer Harris B, Harbour D, Niehoff B, Hirche HJ, Harris R (1998) A high frequency time series at weathership M, Norwegian Sea, during the 1997 spring bloom: feeding of adult female Calanus finmarchicus. Mar Ecol Prog Ser 172:127-137

Jacobsen DM, Anderson DM (1996) Widespread phagocytosis of ciliates and other protists by marine mixotrophic and heterotrophic thecate dinoflagellates. J Phycol 32:279-285

Jakobsen HH, Hansen PJ (1997) Prey size selection, grazing and growth response of the small heterotrophic dinoflagellate Gymnodinium sp. anf the ciliate Balanion comatum - a comparative study. Mar Ecol Prog Ser 158:75-86

Jensen F, Hansen BW (2000) Ciliates and heterotrophic dino£agellates in the marginal ice zone of the central Barents Sea during spring. J Mar Biol Assoc UK 80:45-54

Jeong HJ (1999) The ecological role of heterotrophic dinoflagellates in marine planktonic community. $\mathrm{J}$ Eukaryot Microbiol 46:390-396

Johansson M, Gorokhova E, Larsson U (2004) Annual variability in ciliate community structure, potential prey and predators in the open northern Baltic Sea proper. J Plankton Res 26:67-80. doi: 10.1093/plankt/fbg115

Keck A, Wiktor J, Hapter R, Nilsen R (1999) Phytoplankton assemblages related to physical gradients in an arctic, glacierfed fjord in summer. ICES J Mar Sci 56:203-214

Klein Breteler WCM, Fransz HG, Gonzales HE (1982) Growth and development of four calanoid copepods species under experimental and natural conditions. J Sea Res 16:195-207

Koski M, Wexels Riser C (2006) Post-bloom feeding of Calanus finmarchicus copepodites: selection for autotrophic versus 
heterotrophic prey. Mar Biol Res 2:109-119. doi:110.1080/ 17451000600684367

Kwasniewski S, Hop H, Falk-Petersen S, Pedersen G (2003) Distribution of Calanus species in Kongsfjorden, a glacial fjord in Svalbard. J Plankton Res 25:1-20

Laval-Peuto M, Rassoulzadegan F (1988) Autofluorescence of marine planktonic Oligotrichina and other ciliates. Hydrobiol 159:99-110

Legrand C, Granéli E, Carlsson P (1998) Induced phagotrophy in the photosynthetic dinoflagellates Heterocapsa triquetra. Aquat Microb Ecol 15:65-75

Levinsen H, Nielsen TG (2002) The trophic role of marine pelagic ciliates and heterotrophic dinoflagellates in arctic and temperate coastal ecosystems: a cross-latitude comparison. Limnol Oceanogr 47:427-439

Levinsen H, Nielsen TG, Hansen BW (1999) Plankton community structure and carbon cycling on the western coast of Greenland during the stratified summer situation. II. Heterotrophic dinoflagellates and ciliates. Aquat Microb Ecol 16:217-232

Levinsen H, Turner JT, Nielsen TG, Hansen BW (2000) On the trophic coupling between protists and copepods in Arctic marine ecosystems. Mar Ecol Prog Ser 204:65-77

Lischka S, Hagen W (2005) Life histories of the copepods Pseudocalanus minutus, P. acuspes (Calanoida) and Oithona similis (Cyclopoida) in the Arctic Kongsfjorden (Svalbard). Polar Biol 28:910-921. doi:910.1007/s00300-00005-00017-00301

Loeng H (1991) Features of the physical oceanographic conditions of the Barents Sea. Polar Res 10:5-18

Madsen SJ, Nielsen TG, Tervo OM, Söderkvist J (2008) Importance of feeding for egg production in Calanus finmarchicus and $C$. glacialis during the Arctic spring. Mar Ecol Prog Ser 353:177-190

Mauchline J (1998) The biology of calanoid copepods. Academic Press, San Diego

Menden-Deuer S, Lessard EJ (2000) Carbon to volume relationships for dinoflagellates, diatoms, and other protist plankton. Limnol Oceanogr 45:569-579

Møller EF, Nielsen TG, Richardson K (2006) The zooplankton community in the Greenland Sea: composition and role in carbon turnover. Deep Sea Res I 53:76-93. doi:10.1016/j.dsr.2005. 1009.1007

Nejstgaard J, Gismervik I, Dolberg PT (1997) Feeding and reproduction by Calanus finmarchicus, and microzooplankton grazing during mesocosm blooms of diatoms and the coccolithophore Emiliania huxleyi. Mar Ecol Prog Ser 147:197-217

Nielsen TG, Hansen BW (1995) Plankton community structure and carbon cycling on the western coast of Greenland during and after the sedimentation of a diatom bloom. Mar Ecol Prog Ser 125:239-257

Ogilvie HS (1953) Copepod nauplii (I). Conseil International pour l'Exploration de la Mer. Zooplankton sheet 50

Ohman MD, Runge JA (1994) Sustained fecundity when phytoplankton resources are in short supply: omnivory by Calanus finmarchicus in the Gulf of St. Lawrence. Limnol Oceanogr 39:21-36

Okolodkov YB, Hapter R, Semovski SV (2000) Phytoplankton in Kongsfjorden, Spitsbergen, July 1996. Sarsia 85:345-352

Olli K, Wassmann P, Reigstad M, Ratkova TN, Arashkevich E, Pasternak A, Matrai P, Knulst J, Tranvik L, Klais R, Jakobsen A (2007) The fate of production in the central Arctic Ocean-topdown regulation by zooplankton expatriates? Prog Oceanogr 72:84-113. doi:110.1016/j.pocean.2006.1008.1002

Paffenhofer G, Sherr B, Sherr E (2007) From small scales to the big picture: persistence mechanisms of planktonic grazers in the oligotrophic ocean. Mar Ecol 28:243-253

Pasternak A, Arashkevich E, Reigstad M, Wassmann P, Falk-Petersen S (2008) Dividing mesozooplankton into upper and lower size groups: applications to the grazing impact in the marginal ice zone of the Barents Sea. Deep Sea Res II 55:2245-2256. doi: 2210.1016/j.dsr2242.2008.2205.2002

Pierce RW, Turner JT (1992) Ecology of planktonic ciliates in marine food webs. Rev Aquat Sci 6:139-181

Putt M, Stoecker DK (1989) An experimentally determined carbon: volume ratio for marine "oligotrichous" ciliates from estuarine and coastal waters. Limnol Oceanogr 34:1097-1103

Ratkova TN, Wassmann P (2002) Seasonal variation and spatial distribution of phyto- and protozooplankton in the central Barents Sea. J Mar Syst 38:47-75

Rokkan Iversen K, Seuthe L (2010) Seasonal microbial processes in a high-latitude fjord (Kongsfjorden, Svalbard): I. Heterotrophic bacteria, picoplankton and nanoflagellates. Polar Biol (accepted)

Rysgaard S, Nielsen TG, Hansen BW (1999) Seasonal variation in nutrients, pelagic primary production and grazing in a highArctic coastal marine ecosystem, Young Sound, Northeast Greenland. Mar Ecol Prog Ser 179:13-25

Sabatini M, Kiørboe T (1994) Egg-production, growth and development of the cyclopoid copepod Oithona similis. J Plankton Res 16:1329-1351

Sherr EB, Sherr BF (2007) Heterotrophic dinoflagellates: a significant component of microzooplankton biomass and major grazers of diatoms in the sea. Mar Ecol Prog Ser 352:187-197. doi: $110.3354 /$ meps07161

Sherr E, Sherr BF (2009) Capacity of herbivorous protists to control initiation and development of mass phytoplankton blooms. Aquat Microb Ecol 57:253-262. doi:210.3354/ame01358

Sherr EB, Rassoulzadegan F, Sherr BF (1989) Bacterivory by pelagic choreotrichous ciliates in coastal waters of the NW Mediterranean Sea. Mar Ecol Prog Ser 55:235-240

Sherr EB, Sherr BF, Wheeler PA, Thompson K (2003) Temporal and spatial variation in stocks of autotrophic and heterotrophic microbes in the upper water column of the central Arctic Ocean. Deep Sea Res I 50:557-571

Sherr EB, Sherr BF, Hartz AJ (2009) Microzooplankton grazing impact in the Western Arctic Ocean. Deep Sea Res II 56:1264-1273. doi:1210.1016/j.dsr1262.2008.1210.1036

Sime-Ngando T, Demers S, Juniper SK (1999) Protozoan bacterivory in the ice and the water column of a cold temperate lagoon. Microb Ecol 37:95-106

Smith M, Hansen PJ (2007) Interaction between Mesodinium rubrum and its prey: importance of prey concentration, irradiance and pH. Mar Ecol Prog Ser 338:61-70

Stoecker DK, Michaels AE (1991) Respiration, photosynthesis and carbon metabolism in planktonic ciliates. Mar Biol 108:441-447

Stoecker DK, Silver MW, Michaels AE, Davis LH (1988) Obligate mixotrophy in Laboea strobila, a ciliate which retains chloroplasts. Mar Biol 99:415-423

Svendsen H, Beszczynska-Møller A, Hagen J, Lefauconnier B, Tverberg V, Gerland S, Ørbæk JB, Bischof K, Papucci C, Zajaczkowski M, Azzolini R, Bruland O, Wiencke C, Winther J-G, Dallmann W (2002) The physical environment of Kongsfjorden-Krossfjorden, an Arctic fjord system in Svalbard. Polar Res 21:133-166

Thomas CR (1997) Identifying marine phytoplankton. Academic Press, San Diego

Tillmann U, Hesse KJ (1998) On the quantitative importance of heterotrophic microplankton in the northern German Wadden Sea. Estuaries 21:585-596

Turner JT, Levinsen H, Nielsen TG, Hansen BW (2001) Zooplankton feeding ecology: grazing on phytoplankton and predation on protozoans by copepod and barnacle nauplii in Disko Bay, West Greenland. Mar Ecol Prog Ser 221:209-219

Vaqué D, Guadayol O, Peters F, Felipe J, Angel-Ripoll L, Terrado R, Lovejoy C, Pedrós-Alió C (2008) Seasonal changes in 
planktonic bacterivory rates under the ice-covered coastal Arctic Ocean. Limnol Oceanogr 53:2427-2438

Verity PG, Langdon C (1984) Relationships between lorica volume, carbon, nitrogen, and ATP content of tintinnids in Narragansett Bay. J Plankton Res 6:859-868

Verity PG, Wassmann P, Frischer ME, Howard-Jones MH, Allen AE (2002) Grazing of phytoplankton by microzooplankton in the Barents Sea during early summer. J Mar Syst 38:109-123

Walkusz W, Kwasniewski S, Falk-Petersen S, Hop H, Tverberg V, Wieczorek P, Weslawski JM (2009) Seasonal and spatial changes in the zooplankton community of Kongsfjorden,
Svalbard. Polar Res 28:254-281. doi:210.1111/j.1751-8369. 2009.00107.x

Wiktor J (1999) Early spring microplankton development under fast ice covered fjords of Svalbard, Arctic. Oceanol 41:51-72

Wiktor J, Wojciechowska K (2005) Differences in taxonomic composition of summer phytoplankton in two fjords of West Spitsbergen, Svalbard. Pol Polar Res 26:259-268

Willis KJ, Cottier FR, Kwasnieaski S, Wold A, Falk-Petersen S (2006) The influence of advection on zooplankton community composition in an Arctic fjord (Kongsfjorden, Svalbard). J Mar Syst 61:39-54. doi:10.1016/j.jmarsys.2005.1011.1013 